\title{
Renovation of historical area of the city park
}

\author{
Olga Polyakova ${ }^{1, *}$ \\ ${ }^{1}$ Tolyatti State University, st. Belorusskaya, 14, 445020, Tolyatti, Russia
}

\begin{abstract}
Renovation and improvement of historical area of the Victory Park of the city of Tolyatti, the Samara Region, Russia, are of prime importance in the process of development of cultural environment, since they are aimed at commemorating veterans of the Second World War and its Eastern Front (1941-1945) and the promotion of patriotism among young people. This will also attract domestic and international tourists, which will contribute to the tourism intensification. Architectural and design developments and their implementation correspond the strategies of social and economic development of the city and the region until 2030, they are supported by the Fund of social and cultural development of Tolyatti "Dukhovnoye naslediye" ("Spiritual heritage") and by the city administration. Within the process of design work, the key solutions on landscape renovation, improvement of recreation areas of the park and creation of the platform for related public events were worked out and represented in this paper. Designers elaborated several solutions on a memorial that have specific structural features and include a monument to a female soldier, a homefront worker who was waiting for her husband and bringing up children during hard wartime.
\end{abstract}

\section{Introduction. Problem statement}

The city of Tolyatti, the Samara Region, Russia, is located at the bend of the Volga River that is called Samara Luka, on the left bank of the Kuybyshev Reservoir [1], opposite to the Zhiguli Mountains; figures: 1, 2. Samara Luka National Park and the Zhiguli Nature Reserve are located in the mountains [2,3].



Fig. 1. Samara Luka, Samara-Tolyatti agglomeration located on the left bank of the Volga river, a picture from space

\footnotetext{
${ }^{*}$ Corresponding author: om design@mail.ru
} 


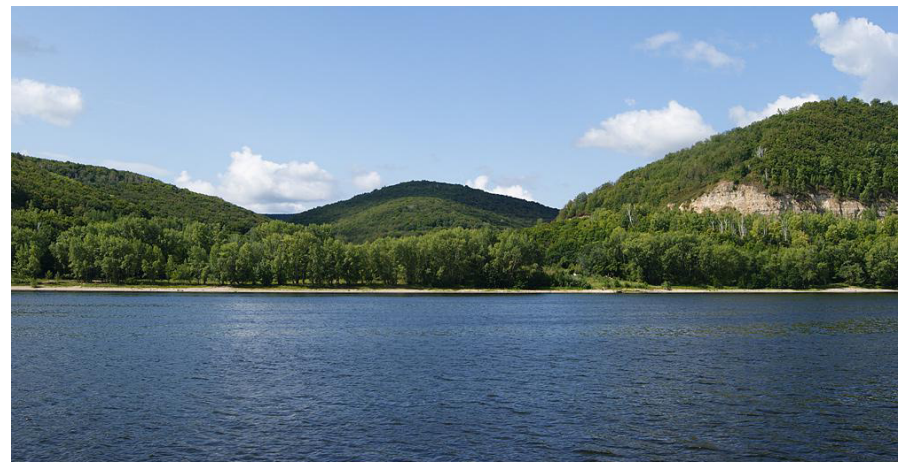

Fig. 2 Zhiguli mountains located on the right coast of Kuibyshev reservoir

Recreational, transport, economic and tourist activities of Tolyatti, which previously was called Stavropol-on-Volga (until 1964), are largely determined by the benefits of using the resources of the Volga basin. The city was founded in 1737 by the statesman Vasily Tatishchev. In 1953-1955, when creating a hydroelectric power station and the Kuibyshev reservoir, it was moved to a new location, since the former territory was flooded.

In 2016 Tolyatti received the status of the Territory of Advance Social and Economic Development $[4,5,6]$, which means that it is an economic zone with preferential tax conditions and other privileges that are defined to attract investment, accelerate economic development and improve the life of the population. The city has a number of cultural centers, recreation areas, technology parks, including one of the largest in Russia Technology park Zhiguli valley [7]. The industrial, economic and social activities of Tolyatti, which is the part of the Samara-Tolyatti agglomeration [8], are provided by the transport infrastructure being under development. In the city there are large systemic companies belonging to the car industry (AvtoVAZ, GM-AvtoVAZ), the chemical industry (Tolyattiazot, Kuibyshevazot) and others; certain types of the territory of the city (Figures $3,4,5,6)$.

In order to accelerate the economic development, improve the life of the population, and increase investment attractiveness, it is necessary, in accordance with the development strategies of the city and the region, to implement certain measures focused on

- stabilizing human resources, attracting youth contingents, professionally trained, promising specialists to the activity in the urban district [9], as well as

- increasing the role of the city and the region of the tourism cluster in the economy, the development of domestic and inbound tourism [10].

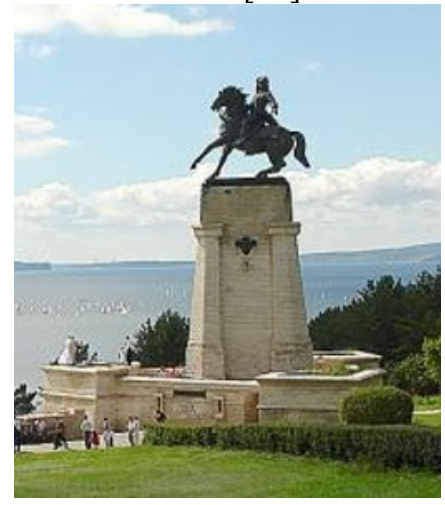

Fig. 3 Monument to Vasily Tatishchev 


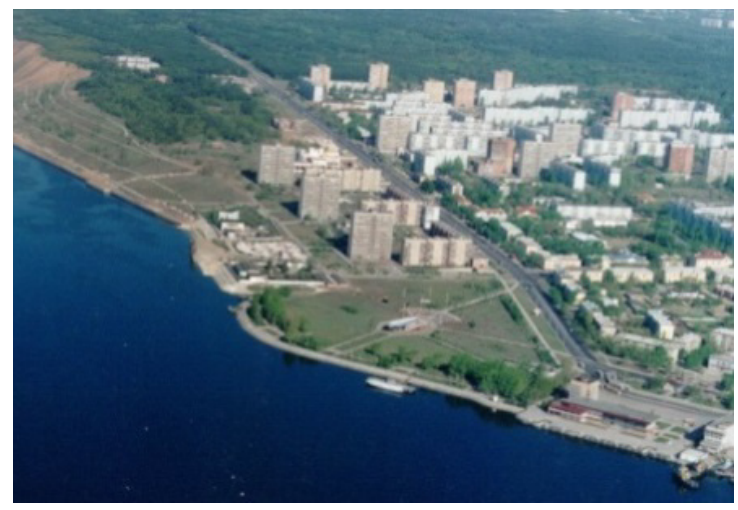

Fig. 4 Embankment, River Station and docks of the city of Tolyatti

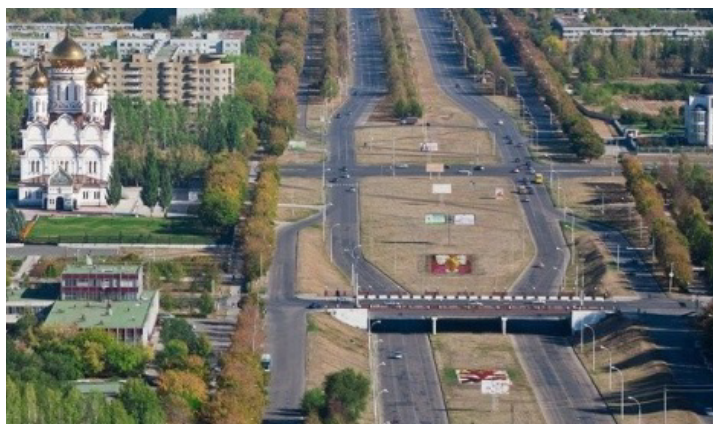

Fig. 5 Highway, Avtozavodsky district of Tolyatti

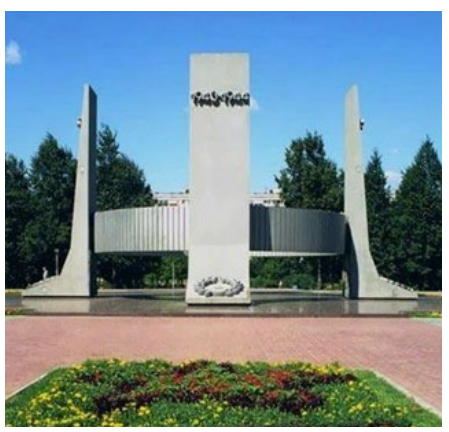

Fig. 6 Victory Park of Tolyatti

The tasks are being solved with the use of technologies for renovation and improvement of the cultural environment of the city, which is peculiar, highly demanded and effective. There are no analogues of these architectural or design solutions.

\section{Architectural design of memory public garden and historical memorial.}

The aims to be achieved, the solution of stabilization and development problems - all this is determined by developing the cultural environment of the city district, which includes the historical area of the Victory Park that is focused on preserving the memory of generations, and supports patriotic education of young people. The presented architectural and design developments are aimed to renovate and improve the particular zone of the park. 
Architectural design of the object $[11,12,13]$ is aimed to form and modernize park's facilities and landscape design means: landscaping, paving the road-path network; creating a platform for specialized events dedicated to the Victory in the war; small architectural forms: benches, trash-bins, lighting elements; the memorial with a monument to a female soldier, a homefront participant, who was waiting for her husband and supporting him, raising children during the difficult war years.

The territory is designed according to the style of formal garden $[14,15,16,17]$, which directs the attention of visitors on the memorial with the monument. Garden paths and paved platforms are formed, lawns in open areas are designed.

Outdoor furniture coated with alkyd enamel is used to increase resistance to temperature and humidity changes. Lighting elements are designed in accordance with additional design solutions.

In modular containers located in separate sections of the territory, symbolic highly demanded cereal crops (rye and wheat) are sown.

The general plan of the territory of the project, with the allocation of sites and a roadpath network, landscaping objects, is shown in figure 7 . The general view of the central part: a functional area with a memorial is shown in figure 8 .

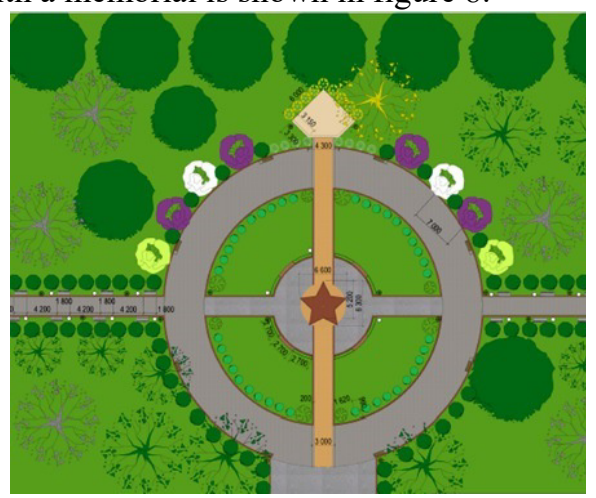

Fig. 7 General plan of the improved area of the park

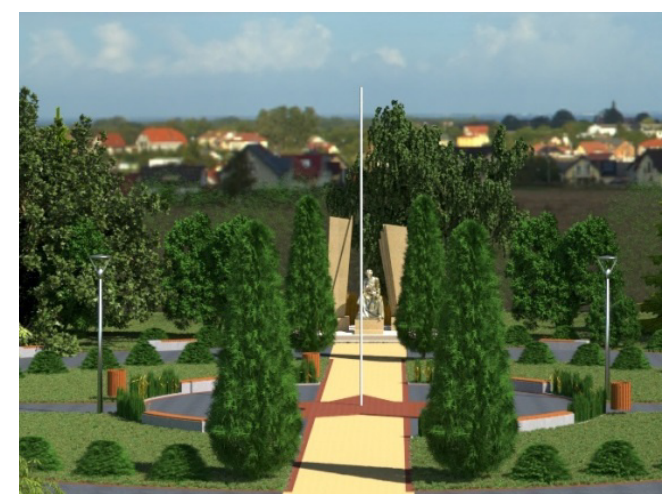

Fig. 8 Functional area of the memorial, general front view

Design solutions including external views of fragments of the functional area of the memorial and recreational lanes with small architectural forms, landscaping and lighting components are shown in figures 9 and 10. 


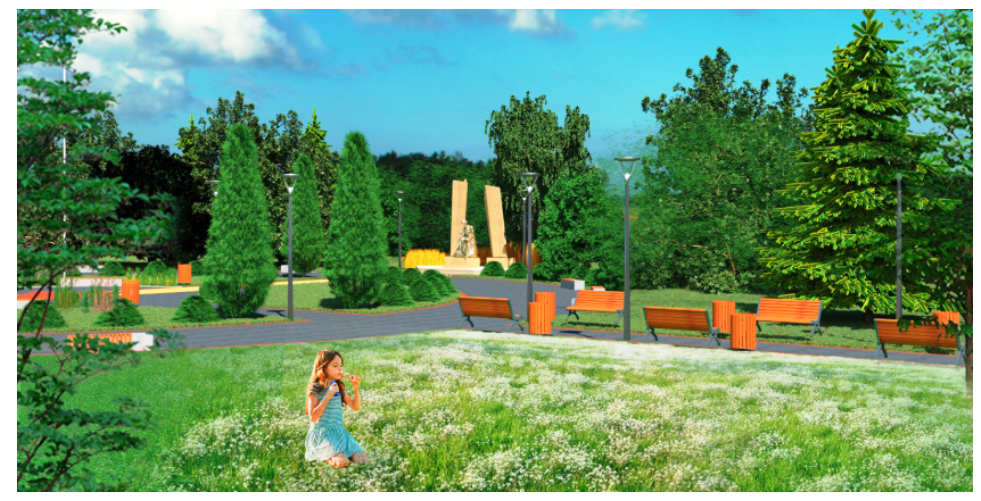

Fig. 9 Visual appearance of the functional area of the memorial and recreational lane with small architectural forms and elements of landscaping

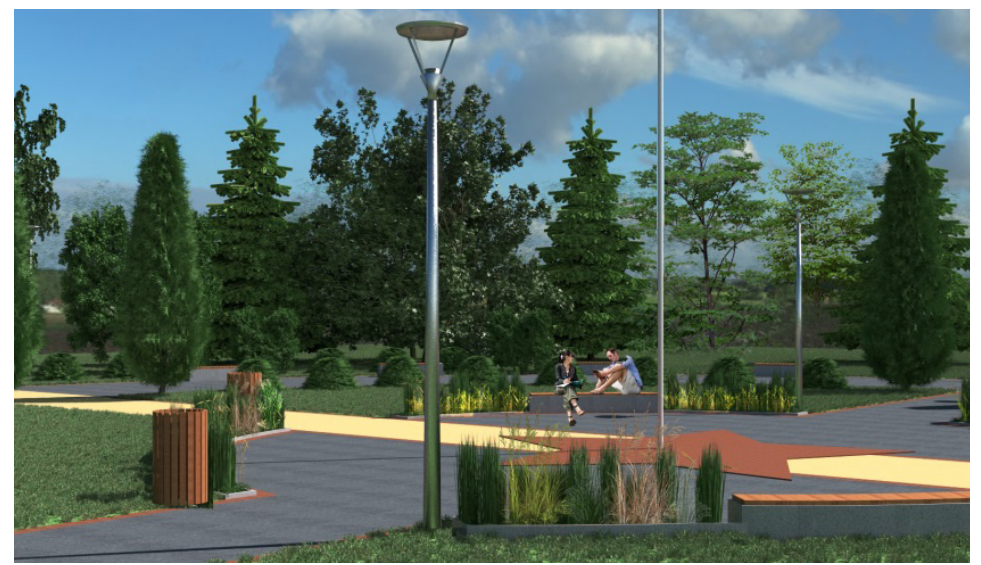

Fig. 10 Visual appearance of recreational lane with small architectural forms, lighting elements, modular containers with symbolic plants

The layout and artistic solutions of the memorial and sculptural forms were worked out in the framework of the open competition. The solutions are represented for analysis, discussion in public organizations and in the divisions of the Tolyatti administration.

The solution for the central zone of the memorial, with the basic component: decorative panels with brass inserts for engraving the front letters is presented in figure 11 .

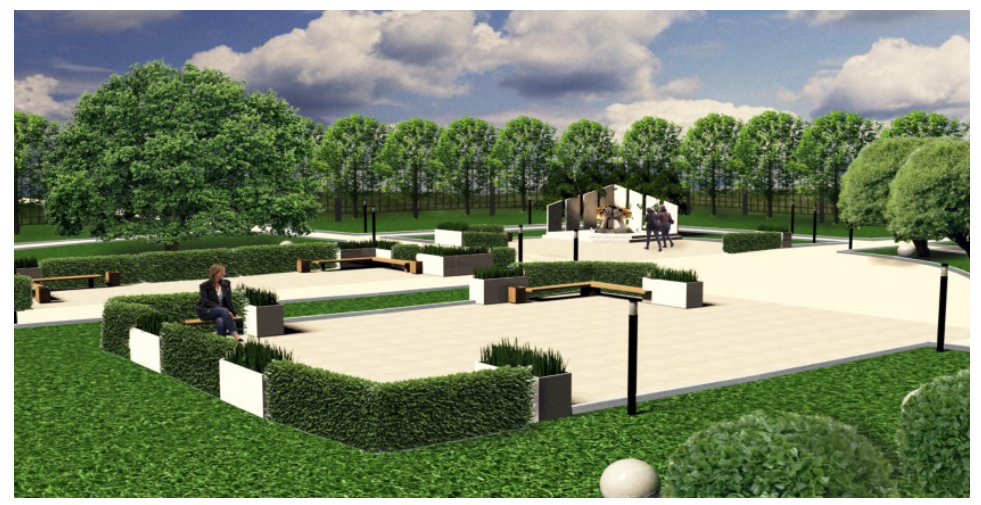

Fig. 11. Visual appearance of the central zone of the memorial, with the core component, in the background - decorative panels with inserts of brass where historical front letters are engraved 
Options for detailing the memorial with a monument to a female soldier, a homefront participant, who was expecting and supporting her husband, raising children during the hard war years, are shown in figures: $12,13,14$.

Alternative options of sculptural artistic solutions of the memorial and the monument, proposed by the authors for discussion, selection and approval are shown in the figures: 15 , $16,17$.

The authors of the sculptural options of the created memorial and monument presented for implementation are: Ivan Ivanovich Melnikov, Samara, assembly of figures: 15; Alexey Mikhailovich. Kuznetsov and Vladislav Ivanovich Pashko, Tolyatti, figures: 16, 17.

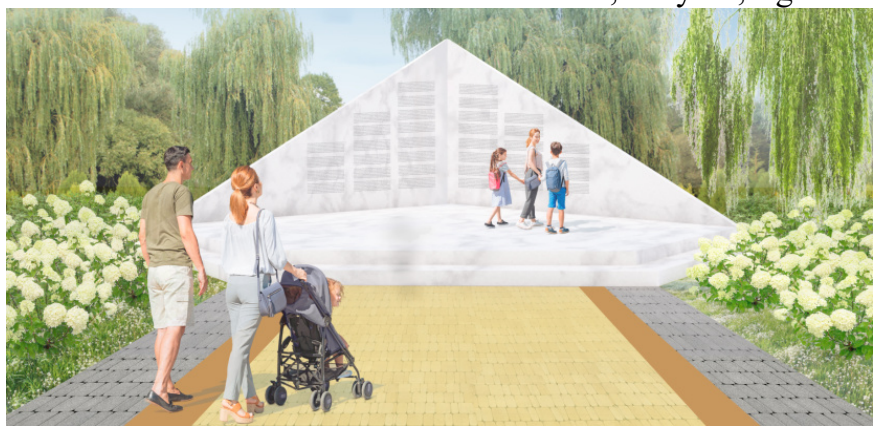

Fig. 12. Visual appearance of the conical panel of the memorial with a viewing platform and inserts where historical front letters are engraved

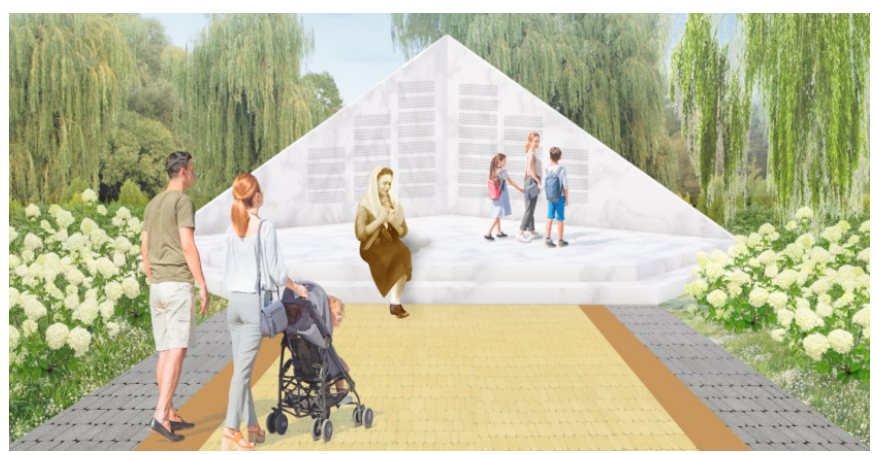

Fig. 13. Visual appearance of the conical panel of the memorial with a viewing platform, the original version of the monument: a female soldier reading a letter

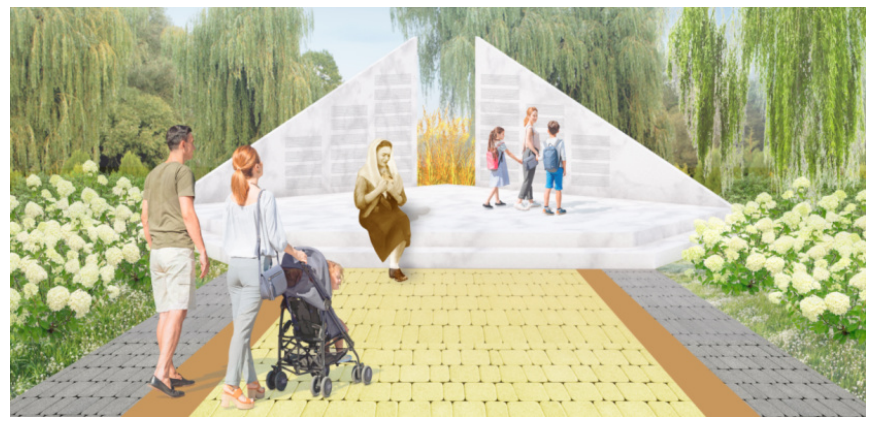

Fig. 14. Option of visual appearance: a memorial panel divided into sections with a viewing platform, the original version of the monument to a female soldier 

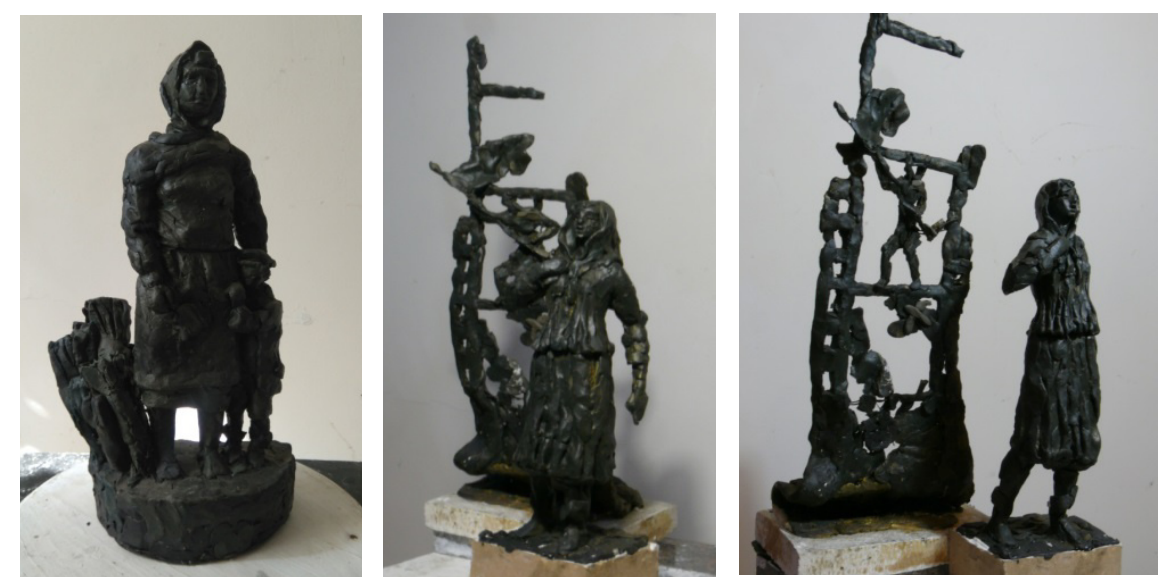

Fig. 15. Options of sculptural solutions for the monument to a female soldier

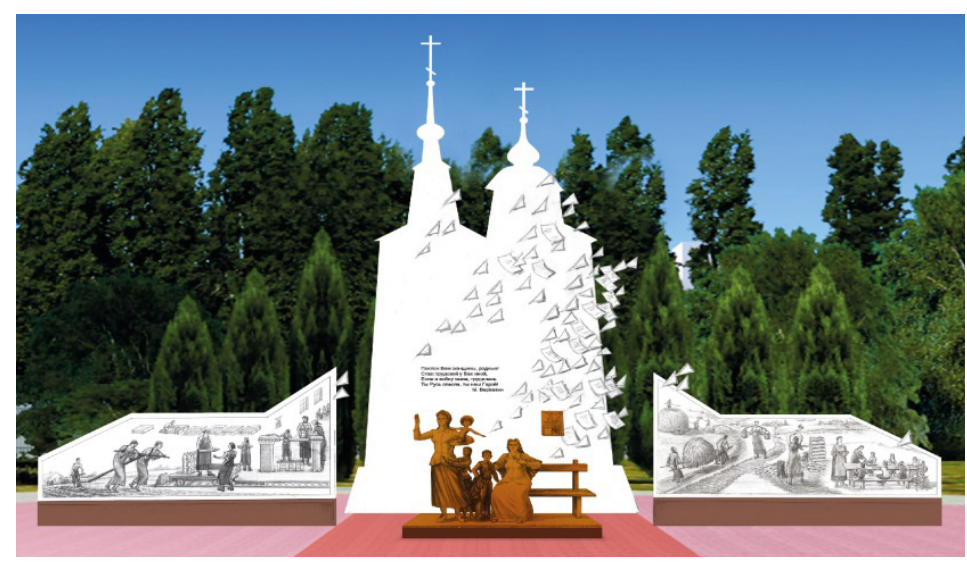

Fig. 16. One of sculptural solutions of the memorial, visual appearance

The competition of artistic solutions and layouts for the memorial and its sculptural forms submitted for analysis and discussion in public organizations and in divisions of the Tolyatti administration will finish in December 2019.

\section{Conclusions}

Renovation and improvement of the historical area of the city park are prepared to educate young people, to support the memory of generations about the role of women during the war, who not only preserved families, but also was replacing front-line soldiers in production, agriculture and training personnel.

The results of the architectural and design developments that are aimed at renovating landscapes, improving the recreational areas of the city park, providing conditions for specialized public events, creating a memorial with a monument to a female soldier, ensure the current development of the cultural environment of the city and the region and support the patriotic education of young people and development of tourist cluster. Public discussions and the choice of the artistic solution for the memorial with a monument contribute to increasing the attractiveness of the new cultural and historical center for citizens and tourists, for excursions that will be held for children and young people. It is 
recommended to intensify and expand areas of work, to create additional cultural and historical centers in cities and other settlements in territories being developed.

\section{References}

1. Istoriya Tol'yatti. Material iz Vikipedii - svobodnoy entsiklopedii [elektronnyy resurs] / URL:https://ru.wikipedia.org/wiki/Istoriya_Tol'yatti.

2. Natsional'nyy park «Samarskaya Luka» http://npsamluka.ru

3. Zhigulevskiy gosudarstvennyy prirodnyy biosfernyy zapovednik im. I.I. Sprygina http://zhreserve.ru

4. Strategiya sotsial'no-ekonomicheskogo razvitiya gorodskogo okruga Tol'yatti do 2030 goda "Tol'yatti - eto lyudi" http://www.tgl.ru/files/files/strategiyatolyatti_predv._11.07.2018_file_1531311229.pdf.

5. Postanovleniye Pravitel'stva RF ot 28.09.2016 №974 «O sozdanii territorii operezhayushchego sotsial'no-ekonomicheskogo razvitiya «Tol'yatti» http://static.government.ru/media/files/AjZHsd9CkJMEvgSOcC1Ax3D6vI6Zddoq.pdf.

6. Strategiya sotsial'no-ekonomicheskogo razvitiya Samarskoy oblasti na period do 2030 goda http://economy.samregion.ru/upload/iblock/82a/strategiya-so_2030.pdf.

7. Technopark in the field of high technology "Zhigulevskaya Valley" http://dolinatlt.ru

8. Samarsko-Tol'yattinskaya_aglomeratsiya. Vikipediya https://ru.wikipedia.org/wiki/SamarskoTol'yattinskaya_aglomeratsiya

9. S.Kh. Peteraytis, O.M. Polyakova, YU.S. Roytburg Karel'skiy nauchnyy zhurnal, 6. 4(21) (2017)

10. Polyakova O.M. Proceedings of the All-Russian Scientific and Practical Conference, 242-247 (2015)

11. Poetapnaya razrabotka arkhitekturno-dizaynerskogo resheniya. Stili arkhitektury i tekhnologii stroitel'stva http://www.arhplan.ru/

12. YU.V. Razumovskiy, L.M. Fursova, V.S. Teodoronskiy Forum (2012)

13. Park Stou. Stowe Landscape Gardens http://landscape.totalarch.com/stowe_landscape_gardens

14. Ye. V. Zabelina Arkhitektura-S (2005)

15. KH. E. Shteynbakh, V. I. Yelenskiy Rech' (2004)

16. Sadovo-parkovoye iskusstvo Rossii. Natsional'nyy turizm http://www.russiaopen.com/2068/2014/07/09/SADOVO-PARKOVOE-ISSKUSTVO-ROSSII.phtml

17. A.P. Vergunov, V.A. Gorokhov Russkiye sady i parki. Landshaftnaya arkhitektura i zelenoye stroitel'stvo http://landscape.totalarch.com/russian_gardens 